\title{
Induction of Bacteriocins from Lactic Acid Bacteria; a Strategy to Improve the Safety of Fresh Fruits and Vegetables
}

\author{
González-Pérez CJ, Aispuro-Hernández E, Vargas-Arispuro I and Martínez-Téllez MA* \\ Centro de Investigación en Alimentación y Desarrollo, AC, Mexico
}

Submission: January 31, 2018; Published: March 13, 2018

"Corresponding author: Martínez-Téllez MA, Centro de Investigación en Alimentación y Desarrollo, A.C. (CIADAC), Km 0.6, Carretera a La Victoria, 83304, Hermosillo, Sonora, México, Tel: 6622892400; Ext: 230; Email: norawa@ciad.mx

\begin{abstract}
Foodborne outbreaks related to the consumption of contaminated fresh fruits and vegetables occur recurrently, despite the implementation of good agricultural and good manufacturing practices, control measures and strict regulations to ensure food safety. Therefore alternative technologies to effectively prevent Foodborne illnesses are necessary. Many lactic acid bacteria exert antagonistic activity against important Foodborne pathogens by producing bacteriocins; toxic compounds of proteic nature that can selectively stop the growth of sensitive bacteria by causing membrane damage or by inhibiting the expression of fundamental genes. Some bacteriocins have already been used in the food industry as natural antimicrobials to prevent the spoilage of food products. This mini-review addresses some strategies for the control of pathogens in fresh fruits and vegetables through the use of bacteriocin-based technologies. The production and incorporation of bacteriocins during pre- and post-harvest handling of fruits and vegetables may be an ecological approach to ameliorate the quality and safety of fresh horticultural products.

Keywords: Foodborne diseases; Food safety; Bacterial antagonism; Bacteriocinogenic; Co-culture; Oligosaccharide
\end{abstract}

\section{Lactic Acid Bacteria for the Potential Control of} Foodborne Diseases

Foodborne diseases (FBD) are a worldwide common and expensive health problem, involving recurrent outbreaks that have even caused the death of consumers. The Food and Drug Administration (FDA), along with the Centers for Disease Control and Prevention are constantly investigating outbreaks related to the consumption of contaminated food in the USA, where enteropathogenic bacteria such as Salmonella spp. and Escherichia coli 0157:H7 are the most frequently found causal agents. For instance, so far in January 2018, the FDA has reported two multistate salmonellosis outbreaks related to the consumption of fresh and frozen fruits and vegetables. Even when the FDA Food Safety Modernization Act, among other issues, establishes requirements for the preventive control of FBD, such as HACCP verification programs, it is estimated that every year there are almost half a million deaths associated with these diseases [1]. Due to this high incidence, novel alternatives are required to reduce the FBD cases and, consequently, the mortality associated with this type of diseases. In addition to the implementation of preventive measures, in case of food contamination during the cultivation, harvesting and processing chain, strong control methods need to be developed to avoid the growth and spread of microbial pathogens, without affecting the quality and acceptance of the food products. A promising strategy is the use of innocuous bacteria with antagonistic activity against FBD causing pathogens. Bacterial antagonism is basically a term used to describe the process by which the growth and proliferation of certain bacteria are inhibited by competing species, often by the production of toxic metabolites that may even be lethal. A well-known group of non-pathogenic bacteria with antagonistic activity against pathogens are Lactic Acid Bacteria (LAB); a very heterogeneous group of Grampositive bacteria, characterized by the production of lactic acid as the main fermentation product. LAB have been ancestrally used for the production of dairy products and, some strains are producers of potent antagonistic substances such as hydrogen peroxide, short-chain fatty acids, antimicrobial peptides, and bacteriocins. Therefore, the use of their antagonistic metabolites, at adequate proportions, is not likely to pose a health concern, but on the contrary, they could be key components for controlling pathogens and ensuring food safety [2].

\section{Bacteriocins Produced by LAB and Their Mode of} Action

Nowadays, nisin, a bacteriocin produced by Lactococcus lactis, is generally recognized as safe (GRAS) by the FDA [3] 
and is currently being used as a preservative agent in the food industry to prevent the growth of Listeria monocytogenes. The commercialization of nisin since the 1950s, triggered the research interest to isolate new bacteriocins from different sources so that by the 1990s, there was a variety of bacteriocins with different activity spectra, some of which are still in the process of seeking approval for use as food additive. Bacteriocins are ribosomally synthesized peptides that when secreted act selectively on other bacteria, permeabilizing its membrane and potentially leading to cell death [4]. Bacteriocins are classified as antimicrobial compounds, similar to the roles played by defensins (produced by mammals) and thionines (produced by plants) [5]. Among the large number of bacteriocins studied so far, LAB are the most frequent producers, including some strains that are able to synthesize up to three bacteriocins with different characteristics [6]. While some bacteriocins act against a highly specific target, some others are known to harm both Grampositive and Gram-negative bacteria [7-10]. The reason of such particularities, along with the regulatory mechanism comprising their production and processing have not been fully elucidated yet, but may vary according to the features of the target bacterial surface and the bacteriocin structural characteristics $[8,11]$. Some bacteriocins are synthesized as precursors that require a post-translational processing such as glycosylation or hydrolysis in specific signaling sequences [12].

The most recent classification for bacteriocins produced by LAB was proposed by Alvarez-Sieiro et al. [13] as follows:

\section{Class I}

Proteins with a molecular weight less than $10 \mathrm{kDa}$ with posttranslational modifications. This class includes those proteins that are prone to undergo some modifications through their biosynthesis, due to the presence of a signal peptide sequence that will allow the recognition, transport, and maintaining of the inactive peptide. These bacteriocins are also characterized for its thermostability.

\section{Class II}

Proteins with a molecular weight less than $10 \mathrm{kDa}$ without post-translational modifications. This class consists of proteins that do not have unusual modifications and do not require any effector for transport. Similar to class I, these bacteriocins are also thermostable.

\section{Class III}

Proteins with a molecular weight greater than $10 \mathrm{kDa}$ without post-translational modifications. These may exert a lytic and non-lytic mechanism of action. Unlike bacteriocins of class I and II, those of class III are thermolabile.

The integrative analysis of common molecular elements found in diverse antagonistic bacterial species has allowed the formulation of a general model integrated by genes and proteins involved in the biosynthesis, modification, secretion, and immunity of bacteriocins $[8,14]$. These elements are regularly present in the same operon coding for the bacteriocin. The production of these antimicrobial molecules in LAB is often under the control of a three-component signal transduction system comprising an inductive factor, a transmembrane protein histidine kinase, and a response regulator. Briefly, this system detects the inducer stimulus and transmits the signal into the cell through phosphorylation-dephosphorylation relays, culminating in the transcription of target genes required for the processing and secretion of bacteriocins (reviewed by [15]).

The mode of action of bacteriocins is one of the mechanisms about bacterial antagonism that has received more attention, mainly due to their similarity to the function of antibiotics. Concisely, bacteriocins can cause the formation of pores in the membrane of sensitive bacteria, which alters cell permeability and decompensates the electrochemical homeostasis. Once inside the target cells, these molecules can bind nucleic acids to prevent gene expression and to interrupt cell biosynthesis $[5,6]$.

\section{Strategies for the induction of bacteriocins}

The production of bacteriocins allows the optimization of nutrient resources by inhibiting the growth of competing species. The mechanisms triggering the synthesis of bacteriocins are still being explored and vary according to the type of producer strain. Some bacterial species follow a constitutive production mode, while a quorum sensing regulation has also been proposed [16]. The constitutive production of bacteriocins often starts toward the end of the log phase and beginning of the stationary phase of growth; however in some species it may start earlier, closer to the middle part of the exponential phase, as in the production of pediocin AcH by Pediococcus acidilactici H [17]. The quorum sensing-controlled production of bacteriocins is related to the bacterial population and to cell-cell communication mediated mainly by small signaling peptides [18].

The $\mathrm{pH}$ and culture medium composition, particularly the type and concentration of carbon source, has a marked impact in the production of bacteriocins $[19,20]$, which may be due to the ability to tune the allocation of nutrients for either growth or for bacteriocins synthesis based on environmental cues [16]. The production of bacteriocins by the LAB Lactobacillus curvatus (Arla-10), Enterococcus faecium (JFR-1), Lactobacillus paracasei ssp. paracasei (JFR-5) and Streptococcus thermophiles (TSB-8) was significantly higher in MRS broth than in BHI broth [19]. These broths differ in the complexity of carbon and nitrogen sources.

Different types of oligosaccharides with varying chemical composition and degree of polymerization, such as inulin derived fructooligosaccharides (FOS) [20], galactooligosaccharides produced from lactose [21], and xylooligosaccharides obtained from wood xylans [22] induce the growth and antagonistic activity of LAB by promoting metabolic adjustments that enhance the production of antimicrobial compounds. Particularly, FOS supplementation enhanced the spectrum and 
antimicrobial activity of bacteriocins produced by Lactobacillus strains (L. plantarum, L. casei, and L. brevis) isolated from corn ensilage and molasses against FBD-related pathogens [20]. Likewise, supplementation of MRS with the di- and trisaccharides lactulose and raffinose, respectively, increased the bacteriocinogenic activity of $L$. paracasei CMGB16 against $E$. coli [23]. Interestingly, supplementation with the disaccharide trehalose was reported to promote the growth of L. lactis ssp. lactis C101910 and Lactococcus sp. GM005 and to augment the production of bacteriocins even to a greater extent than FOS [24]. In recent years, some pectic derived oligosaccharides (POS) have begun to be proposed as potential prebiotic substances, due to their capacity to stimulate the growth of probiotic LAB $[25,26]$. Recent findings in our research group indicate that supplementation of LAB cultures with oligogalacturonides (the most abundant type of POS), with a degree of polymerization from 3 to 20, enhances their antagonistic activity against FBDrelated pathogens. Therefore, oligogalacturonides may become promising inductors for the production of bacteriocin-like inhibitory substances.

The induction of bacteriocin synthesis by co-culture of the producer LAB strain with competitor species has lately demonstrated to be an effective strategy to maintain their ability to produce these antimicrobial compounds [18]. Additionally, co-culture methods have proved to enhance the antimicrobial activity of LAB and to increase the production of bacteriocins in comparison with monocultures, in a strain-specific manner [27]. The ability to induce the synthesis of bacteriocins in a different bacterial species may be developed by either related or unrelated microorganisms, however, the relationship between bacteriocin-inducing and bacteriocin-producing strains is not well understood yet [18]. Also, inductor strains may or not be susceptible to the bacteriocins synthetized by producer LAB strains. On the contrary, some reports indicated that co-culturing bacteriocin-producing LAB strains with known inductor strains either did not increase the production of bacteriocins [28] or suppressed their production [29]; overall indicating that the co-culture-inducible synthesis of bacteriocins is likely to be strain specific. Among the LAB bacteriocins successfully induced through co-culture strategies so far are lactacin B, kimchicin G7, paracin 1.7, and plantaricins A, NC8 and MG (Reviewed by [18]), gassericin E [30], and pediocin [31].

\section{Role of bacteriocins produced by LAB in the development of innovative safety strategies for fresh vegetable products}

Several bacteriocins have already been used as natural antimicrobials to prevent spoilage of diverse food products and simultaneously reduce the concentration of synthetic additives. Although there are many bacteriocins produced by antagonistic LAB strains isolated from vegetable food products (Reviewed by [32]), the most studied food matrices with incorporated bacteriocins have been meat- and dairy-based products. The activity of bacteriocins on fruits and vegetables seems to vary according to the type of food product. The bacteriocin enterocin 416K1 (produced by Enterococcus casseliflavus IM 416K1) was able to completely kill $L$. monocytogenes from contaminated processed apple and grapes within $8 \mathrm{~h}$ posttreatment; however, no considerable inhibition of this pathogen was observed for processed pineapple and melon fruits [33]. Likewise, enterocin AS-48, produced by Enterococcus faecalis A-48-32, inhibited L. monocytogenes growth in whole raspberries and sliced strawberries and blackberries stored at low temperatures [34].

Bacteriocins share important features that allow them to be used in the food industry; they are resistant to surfactants, active in a wide $\mathrm{pH}$ range and they are often thermostable [13]. Also, a prerequisite prior to the application of newly discovered bacteriocins in food products intended for human consumption is their sensitivity to digestive proteases. Purified bacteriocins may be added directly to the food matrix as a food additive or applied as coatings using a carrier matrix; alternatively, if bacteriocins are produced naturally by food-grade bacteria, the producer strain may be considered GRAS and can be inoculated for the production of fermented food [35].

Considering fresh fruits and vegetables are natural reservoirs of LAB, the screening of epiphytic bacteriocinogenic strains isolated from their surfaces would provide novel bacteriocinproducing strains adapted to the same environmental conditions used for the growth and storage of fresh horticultural products. The incorporation of bacteriocins-based technologies to avoid the proliferation of pathogens in these type of fresh foods may be achieved through either one of the following strategies or their combination:

A. The application of prebiotic oligosaccharides on the surface of fruits and vegetables, for inducing the production of bacteriocins by epiphytic LAB;

B. The inoculation of these products with GRAS bacteriocin-producing LAB;

C. The application of active antimicrobial films or coatings containing commercially available bacteriocins.

In summary, the use of bacteriocins on fresh horticultural products may be an ecological alternative to combat pathogens and ameliorate the incidence of FBD. The production of bacteriocins in sufficient amounts is a challenge that may be addressed through the use of inductor substances or by coculture strategies with inductor strains. Future research should highlight the importance of screening for novel bacteriocinproducing LAB strains isolated from unusual sources and under variable growing conditions, which may also lead to the discovery of new bacteriocins with a different spectrum or to the enhancement of their antibacterial activity.

\section{Conclusion}

The production of bacteriocins by lactic acid bacteria and their subsequent incorporation during pre- and post-harvest 
handling of fruits and vegetables could improve the quality and safety of fresh horticultural products in an ecological manner. The induction of bacteriocin synthesis by adopting the strategies addressed hereby would play a crucial role in the effectiveness of this approach.

\section{References}

1. WHO (2015) Food Safety.

2. O'sullivan L, Ross RP, Hill C (2002) Potential of bacteriocin-producing lactic acid bacteria for improvements in food safety and quality. Biochimie 84(5-6): 593-604.

3. Cano-Garrido O, Seras-Franzoso J, Garcia-Fruitós E (2015) Lactic acid bacteria: reviewing the potential of a promising delivery live vector for biomedical purposes. Microb Cell Fact 14(1): 137.

4. Jordan K, Dalmasso M, Zentek J, Mader A, Bruggeman G, et al. (2014) Microbes versus microbes: control of pathogens in the food chain. J Sci Food Agric 94(15): 3079-3089.

5. Karpiński TM, Szkaradkiewicz AK (2013) Characteristic of bacteriocines and their application. Pol J Microbiol 62(3): 223-235.

6. Snyder AB, Worobo RW (2014) Chemical and genetic characterization of bacteriocins: antimicrobial peptides for food safety. J Sci Food Agric 94(1): 28-44.

7. Miller P, McMullen LM (2014) Mechanism for temperature-dependent production of piscicolin 126. Microbiol 160(8): 1670-1678.

8. Perez RH, Ishibashi N, Inoue T, Himeno K, Masuda Y, et al. (2016) Functional analysis of genes involved in the biosynthesis of Enterocin NKR5-3B, a novel circular bacteriocin. J Bacteriol 198(2): 291-300.

9. Venema K, Kok J, Marugg JD, Toonen MY, Ledeboer AM, et al. (1995) Functional analysis of the pediocin operon of Pediococcus acidilactici PAC1. 0: PedB is the immunity protein and PedD is the precursor processing enzyme. Mol Microbiol 17(3): 515-522.

10. Abee T, Rombouts FM, Hugenholtz J, Guihard G, Letellier L (1994) Mode of action of nisin $\mathrm{Z}$ against Listeria monocytogenes Scott A grown at high and low temperatures. Appl Environ Microbiol 60(6): 1962-1968.

11. Gabrielsen C, Brede DA, Nes IF, Diep DB (2014) Circular bacteriocins: biosynthesis and mode of action. Appl Environ Microbiol 80(22): 6854-6862.

12. Kaškonienė V, Stankevičius M, Bimbiraitè-Survilienė K, Naujokaitytė G, Šernienè L, et al. (2017) Current state of purification, isolation and analysis of bacteriocins produced by lactic acid bacteria. Appl Microbiol Biotechnol 101(4): 1323-1335.

13. Alvarez-Sieiro P, Montalbán-López M, Mu D, Kuipers OP (2016) Bacteriocins of lactic acid bacteria: extending the family. Appl Microbiol Biotechnol 100(7): 2939-2951.

14. Todorov SD (2009) Bacteriocins from Lactobacillus plantarum production, genetic organization and mode of action. Braz J Microbiol 40(2): 209-221.

15. Cintas L, Casaus M, Herranz C, Nes I, Hernández P (2001) Bacteriocins of lactic acid bacteria. Food Sci Technol Int 7(4): 281-305.

16. Blanchard AE, Liao C, Lu T (2016) An ecological understanding of quorum sensing-controlled bacteriocin synthesis. Cell Mol Bioeng 9(3): 443-454.

17. Biswas S, Ray P, Johnson M, Ray B (1991) Influence of growth conditions on the production of a bacteriocin, pediocin $\mathrm{AcH}$, by Pediococcus acidilactici H. Appl Environ Microbiol 57(4): 1265-1267.

18. Chanos P, Mygind T (2016) Co-culture-inducible bacteriocin production in lactic acid bacteria. Appl Microbiol Biotechnol 100(10): 42974308.
19. Yang E, Fan L, Yan J, Jiang Y, Doucette C, et al. (2018) Influence of culture media, $\mathrm{pH}$ and temperature on growth and bacteriocin production of bacteriocinogenic lactic acid bacteria. AMB Express 8(1): 10.

20. Munoz M, Mosquera A, Almeciga-Diaz C, Melendez A, Sanchez 0 (2012) Fructooligosaccharides metabolism and effect on bacteriocin production in Lactobacillus strains isolated from ensiled corn and molasses. Anaerobe 18(3): 321-330.

21. Macfarlane G, Steed H, Macfarlane S (2008) Bacterial metabolism and health-related effects of galacto-oligosaccharides and other prebiotics. J Appl Microbiol 104(2): 305-344.

22. Nieto-Domínguez M, de Eugenio LI, York-Durán MJ, Rodríguez-Colinas B, Plou FJ, et al. (2017) Prebiotic effect of xylooligosaccharides produced from birchwood xylan by a novel fungal GH11 xylanase. Food Chem 232: 105-113.

23. Vamanu E, Vamanu A (2010) The influence of prebiotics on bacteriocin synthesis using the strain Lactobacillus paracasei CMGB16. Afr J Microbiol Res 4(7): 534-537.

24. Chen YS, Srionnual S, Onda T, Yanagida F (2007) Effects of prebiotic oligosaccharides and trehalose on growth and production of bacteriocins by lactic acid bacteria. Lett Appl Microbiol 45(2): 190-193.

25. Gómez B, Gullón B, Remoroza C, Schols HA, Parajó JC, et al. (2014) Purification, characterization, and prebiotic properties of pectic oligosaccharides from orange peel wastes. J Agric Food Chem 62(40): 97699782.

26. Manderson K, Pinart M, Tuohy K, Grace W, Hotchkiss A, et al. (2005) In vitro determination of prebiotic properties of oligosaccharides derived from an orange juice manufacturing by-product stream. Appl Environ Microbiol 71(12): 8383-8389.

27. Maldonado-Barragán A, Caballero-Guerrero B, Lucena-Padrós H, Ruiz-Barba JL (2013) Induction of bacteriocin production by coculture is widespread among plantaricin-producing Lactobacillus plantarum strains with different regulatory operons. Food Microbiol 33(1): 40-47.

28. Ahn H, Kim J, Kim WJ (2017) Isolation and characterization of bacteriocin-producing Pediococcus acidilactici HW01 from malt and its potential to control beer spoilage lactic acid bacteria. Food Control 80: 59-66.

29. Domínguez-Manzano J, Jiménez-Díaz R (2013) Suppression of bacteriocin production in mixed-species cultures of lactic acid bacteria. Food Control 30: 474-479.

30. Maldonado-Barragán A, Caballero-Guerrero B, Martín V, Ruiz-Barba JL, Rodríguez JM (2016) Purification and genetic characterization of gassericin E, a novel co-culture inducible bacteriocin from Lactobacillus gasseri EV1461 isolated from the vagina of a healthy woman. BMC Microbiol 16(1): 37.

31. Somkuti GA, Steinberg D.H (2010) Pediocin production in milk by Pediococcus acidilactici in co-culture with Streptococcus thermophilus and Lactobacillus delbrueckii subsp. bulgaricus. J Ind Microbiol Biotechnol 37(1): 65-69.

32. Settanni L, Corsetti A (2008) Application of bacteriocins in vegetable food biopreservation. Int J Food Microbiol 121(2): 123-138.

33. Anacarso I, De Niederhaeusern S, Iseppi R, Sabia C, Bondi M, et al. (2011) Anti-listerial activity of chitosan and Enterocin 416K1 in artificially contaminated RTE products. Food Control 22(12): 2076-2080.

34. Molinos AC, Abriouel H, López RL, Omar NB, Valdivia E, et al. (2008) Inhibition of Bacillus cereus and Bacillus weihenstephanensis in raw vegetables by application of washing solutions containing enterocin AS-48 alone and in combination with other antimicrobials. Food Microbiol 25(6): 762-770.

35. O’Bryan CA, Koo OK, Sostrin ML, Ricke SC, Crandall PG, et al. (2018) Characteristics of bacteriocins and use as food antimicrobials in the United States, in Food and Feed Safety Systems and Analysis. Elsevier, Netherlands, pp. 273-286. 
This work is licensed under Creative Commons Attribution 4.0 License

DOI: 10.19080/ARTOAJ.2018.14.555927
Your next submission with Juniper Publishers will reach you the below assets

- Quality Editorial service

- Swift Peer Review

- Reprints availability

- E-prints Service

- Manuscript Podcast for convenient understanding

- Global attainment for your research

- Manuscript accessibility in different formats

( Pdf, E-pub, Full Text, Audio)

- Unceasing customer service

Track the below URL for one-step submission https://juniperpublishers.com/online-submission.php 